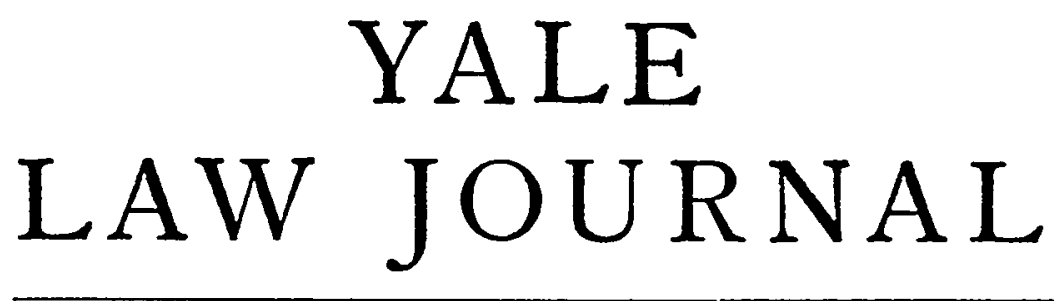

Vor. X. NOVEMBER, $1900 . \quad$ No. 1

\title{
THE PART TAKEN BY COURTS OF JUSTICE IN THE DEVELOPMENT OF INTERNATIONAL LAW.
}

[DELIVERED BY SIMEON E. BALDWIN, LI.D., AS HIS INAUGURAL, ADDRESS AS PRESIDENT OF THE INTERNATTONAI LAW ASSOCIATION, AT ITS 19TH CONFERENCE, AT ROUEN, ON AUGUST 21, 1900.]*

The science which it is the purpose of this Association to cultivate and advance first took shape and form in the brilliant capital of the great people among whom we are met to-day. An Englishman, long afterwards, gave it its name, 1 but Paris was its birth-place, for there, in 1625 , Grotius, hospitably received by Louis XIII, whenflying from his own country as a condemned criminal, dedicated to him and published to the world his de Jure Belli ac Pacis.

Oxford had indeed, in the preceding generation, had among her professors one who had written systematically on the law of war, and there were countrymen of Gentilis, whose works issued from the Italian press treated of the same subject, and from a point of view not wholly different. ${ }^{2}$ We all know that there are adumbrations preceding every new discovery, which, it is afterwards seen, pointed to it in some uncertain or half

* Printed in the YaLs Law Jourral by permission of the Association in advance of its appearance in its transactions.

1 Jeremy Bentham, in 1789.

2 Holland, Studies in International Law, I, II. 
certain way. The real discoverer nevertheless is he who gives form and precision to what before was vague and ill-defined. ${ }^{3}$

The foundations upon which Grotius built are familiar to us all. The jus gentium of the Romans he treated as largely the expression of natural $1 \mathrm{aw}, 4$ and natural law as the rightful rule of conduct to govern the relations of associated bodies of men, grouped into separate States, no less than those of their individual members to each other. ${ }^{5}$ He was thus able to appeal to an established system of jurisprudence, venerable from its antiquity, ready at hand and at least approximately adequate in principle, when studied in the light of divine revelation, to regulate international intercourse under the conditions of modern civilization. 6 The protection of natural law might, indeed, as to certain points, be renounced, and thus a rule established by the jus gentium totally inconsistent with the jus naturale, as where by engaging in war one impliedly consents to submit himself to the will of the conqueror, and so from a freeman may become a slave. But, as a whole, what all men, in all nations, have recognized as properstandards of human conduct, Grotius insisted had a natural claim to be accepted, so far as they might be applicable as a jus not merely inter homines, but inter populos.

It was fortunate that the Civil law could supply a term so elastic, and perhaps ambiguous, as that of jus gentium. The most critical of modern scholars cannot deny that the Romans often referred to it as a rule in matters of international obligation, 7 though it is no less certain that they viewed it as of narrow application in this respect, and that it is the moderns rather than the ancients that havegiven it a philosophical basis in moral and religious principles of action. ${ }^{8}$ Nor, at its best, as Grotius fully recognized, was it more than a scanty and fragmentary collection. If the new system was to extend far,

8 Grotius, de Jure Belli ac Pacis, prolegomena, 30, 36, 38.

4 de Jure Belli ac Pacis, I, 1, xiv; II, 8, i, xxvi, 18, i, 20, xl.

- Ibid., prolegomena, 17.

- Ibid., proleg., 53. Cf. The Maria, 1 Rob. Adm. Rep. 340.

7 Livy II, iv, XXI, x; Sallust, Bell. Jugurth., XXXV. The jus publicum Romanum may fairly be said to rest largely on the jus gentium, as to the rights of war, the obligation of treaties, title to the goods of a foreigner, the jus postliminii, and the personal inviolability of ambassadors. See Dig. XLIX, 15, de Captivis et de Postliminio, 5, 11, 19; Postlimininm est jus inter nos ac liberos populos regesque, moribus, legibus, constitutum.

8 Montesquieu, Esprit des Lois, I, 3. 
if it was to achieve great things, if it was to elevate the jus humanum by its insistence on the jus divinum, if it was to give certainty to speculative doctrine, sanction to public opinion, it must draw from other sources, and appeal to better authority than Greek philosophy or Roman precedent.

I venture to think that the service rendered in this direction from time to time by the courts of justice has not always been estimated at its full weight.

The way had been prepared by the natural and almost necessary course of admiralty jurisdiction in civil causes. There is one, and but one, part of the surface of the earth which belongs equally to all men. The ocean can know no master but the storm. The necessities of commerce have therefore driven the civilized world to accept a law merchant framed for its protection by those most interested in its pursuit. The customs of trade, whether it be trade by land or sea, soon become the rule by which mercantile adventures are to be governed, if the subject of judicial inquiry.

Ocean navigation was in its infancy when Grotius wrote. That the sea was open and free to all comers was by no means universally admitted. A quarter of a century had hardly elapsed since the invention of Daris' quadrant. The application of logarithms to nautical calculations, and the introduction of middle latitude sailing were still more recent.

Voyages soon became longer; cargoes richer; maritime casualties more frequent. Suits between merchants of different nationalities began to crowd the courts. What law should be applied? That of the actor, or of the reus; of the forum, or of the world?

The courts of every country have ordinarily treated the general maritime law, so far as it could beconsidered as settled, and was not contrary to the expressed will of the sovereign by whom they were commissioned, as being by usage a part of the common or unwritten law to which they had a right to resort. 9 If the parties before them are all of nations acknowledging a different (and the same) law on the point in question, that law may be applied; but in any other case they must take the general maritime law recognized in the forum whose aid has been invoked.10 Of this law, the Corpus Juris Civilis, so

- The Lottawanna,21 Wallace's Reportn, 558, 672; Liverpool Steam Co. 7. Phenix Ins. Co., 129 United States Reports, 444. 
far as it went, was from the first universally considered an authentic repository. ${ }^{11}$

But the court of admiralty as an instance court was also called upon to punish offenses committed upon the sea, and, when given the functions of a prize court, to pass upon the broadest questions of public right. It was natural and almost inevitable for each sovereign to instruct his judges that in these matters also, unless specially directed to the contrary, they were to proceed in a similar way, looking to the general law of the sea, and to the rules of public law, affecting maritime events, which might be commonly regarded as of international obligation. ${ }^{12}$

In England, an unfortunate conflict of opinion between the common law and the admiralty judges as to the limits of the jurisdiction of their courts, retarded for a time the orderly development of the principles of international law applicable to maritime events. Criminal prosecutions even for offenses com. mitted upon the high seas were anciently tried in the King's Bench. ${ }^{13}$ For many centuries, however, they have been the acknowledged subject of admiralty jurisdiction, and the great judges who have succeeded to the functions of the admiral have, by many important decisions, helped to solidify and systematize the public law of the sea.

Perhaps the most widely known of these judgments has not met with the widest acceptance. In the case of the Franconia, it was held that a sovereign may inrest his courts with the right to punish such acts as he may declare to be criminal offenses, when committed on the high seas, if within the threemile limit, though by a foreigner against a foreigner and upon a foreign ship. ${ }^{14}$ The legislative department of Great Britain, in recognizing this doctrine, and providing for its enforcement,

10 The Scotland, 105 United States Reports, 24, 29; The Belgenland, 114 United States Reports, 355, 369.

11 See Clerke. Praxis Supremae Cariae Admiralitatis, 98.

12 The ancient form of the commission to the English Admiralty Judges to act an a Prize Court, directed them to proceed "according to the course of the Admiralty, and the law of nations." Douglas' Rep. "592, note. The same language was adopted in the first ordinance passed upon this subject by the United States. 7 Journals of Congress, 68 (1781). Cf. 6 ibid. 21 (1780).

18 Lord Hale's Treatise on Admiralty Jurisdiction, in the Hargrave Mss., quoted in Commonwealth r. Macloon, 101 Massachusetts Reports, 1, 12.

14 Regina ४. Keyn, Law Reports, 2 Exchequer Division, 53. 
however, thought it necessary to forbid its application in any case without the consent of one of the Secretaries of State. ${ }^{16}$ With this limitation it is safe to say that the claims of jurisdiction asserted in the Keyn case will not be pursued by criminal proceedings against a foreigner, under circumstances which could give a just cause of complaint to the country of his allegiance. ${ }^{10}$

It is the good fortune of the branch of jurisprudence which it is our task to extend, that it grows in war no less than in peace, perhaps we might say, more than in peace. The rule that Inter arma silent leges has but slight application to courts whose office it is to administer the law of nations respecting captures on the sea.

The weighty words uttered a hundred years ago by Sir William Scott in the case of the Maria have often been criticised, but I believe they express a true conception of official daty:

"I trust that it has not escaped my anxious recollection for one moment, what it is that the duty of my station calls for from me; namely, to consider myself as stationed here, not to deliver occasional and shifting opinions to serve present purposes of particular national interest, but to administer with indifference that justice which the law of nations holds out, without distinction, to independent Staies, some happening to be neutral and some to be belligerent. The seat of judicial authority is, indeed, locally here, in the belligerent country, according to the known law and practice of nations: but thelaw itself has no locality. It is the duty of the person who sits here to determine this question exactly as he would determine the same question if sitting at Stockholm ; to assert no pretensions on the part of Great Britain which he would not allow to Sweden in the same circumstances, and to impose no duties on Sweden, as a neutral country, which he would not admit to belong to Great Britain in the same character. If, therefore, I mistake the law in this matter, I mistake that which I consider, and which I mean should be considered, as the universal law upon the question." 17

It has been said that the King of England sees in the two

15 Act of 40 and 41 Vict. Chap. 73.

10 See the rules as to the mer territoriale adopted by the Institute of Interantional Law in 1894.

17 The Maria, 1 C. Robineon's Reports, 340. The Ost See, 9 Moore, Priry Council Cases, 141; Note in Cobbett's Cases on Int. Law 220. 
houses of parliament his equals; in the law his superior. International law, when administered in the lofty spirit of Lord Stowell, may make a still bolder claim. It is superior not to any king, but to any nation.

A nation may indeed disown and reject its rules, but only, if this be done avowedly and persistently, at the cost of becoming a sort of outlaw in civilized society.

It must be frankly owned, however, that the court which seeks to declare and administer a universal law must sometimes make it for itself. It finds the authorities in conflict, and it chooses between them. It looks to civilized society in its largest sense for its guide; but simply because common acceptance and general usage are the main sources of authority for rules of decision in admiralty and prize courts, their judges have been, from the first, compelled often to take the part of legislators, in settling the form of maritime law.

Nor was this true of those having admiralty jurisdiction alone. In whatever court title was set up under a foreign decree in rem, rendered in admiralty, it became necessary to ask whether that decree was so framed and rendered as to work a transfer, which by the comity of nations was entitled to respect.

Was a ship sold as prize by order of the courts of a neutral, or of a country into which she had not been brought, and afterwards found in a port of a different power by her original owner? He had a right to demand that the validity of her condemnation should be re-examined in the new forum, so far as to determine whether it had been obtained in accordance with the laws of nations. 18

So, on the other hand, if a ship captured in war were sold by the captor without resort to a foreign court, she could be reclaimed by her original owner before any of the ordinary tribunals having cognizance of questions of title, because they had the right to pronounce that under the laws of nations no effectual transfer had been made. ${ }^{19}$

In constitutional monarchies the decision given in such a case was governed by those laws, not because that rule might have been prescribed by royal commission, but rather on the

\footnotetext{
18 Rose ₹. Himely, 4 Cranch's Rep., 241.

19 Assievedo r. Cambridge, 10 Modern Rep., 79; Lindo r. Rodneg, Douglas' Rep., 691.
} 
ground that no other could have been. ${ }^{20}$ The king could not of himself create or vary the law of the land, nor the law of the sea. That required the concurrence of the legislative power. He could only choose those who were to administer the existing law. Hence, the judges were driven to assert that the law of nations was part of the unwritten law of the land, and (to justify this position) to rest it in great part on an unchanging and unchangeable jus naturale, which in turn it was for them to declare. ${ }^{21}$

The same ground has been taken by the courts sitting under republican governments. ${ }^{22}$

In absolute monarchies the judges being the mouthpieces of the sovereign, and their sentences subject to his overruling power, their function was more restrained.

Indeed, in all countries where there is no constitutional provision to the contrary, an appeal has been given in prize cases to the executive power, and their ultimate decision been treated as largely a question of State policy. ${ }^{23}$ Such an appeal, however, cannot in fairness be decided upon any other rules than those prescribed for the court of first instance, which have rarely been other than such as are to be found in the law of nations. Whenever any other course has been taken, the voice of public opinion sooner or later has condemned it, nor has it in its nature the force of a strictly judicial precedent.

In England, the position that the law of nations is a part of the municipal law was first, so far as is disclosed by the reports of decided cases, asserted from the bench by Lord Talbot, in 1736. ${ }^{24}$ He found no warrant for it in the earlier institutional writers of his country, although many of them were civilians. One of the most authoritative, St. Germain, the author of "Doctor and Student," written early in the sixteenth century, in enumerating its various kinds and sources, has nothing to say of the law of nations, though the jus gentium, in its Roman acceptation, is mentioned as inferior in authority

30 Key 7. Pearse, Douglas' Rep., 584, 586; Letter of the Duke of Nercastle to the Prussian legation, in 1753, given in Chitty, Law of Nations, appendix, 309.

21 Blackstone's Commentaries on the Laws of England, IV, 67; I, 43; Triquet v. Bath, 3 Burrow's Rep. 1480, 1481.

22 Henfield's Case, Wharton's State Trials, 52, 61, 62.

28 Azuni, Maritime Lav of Europe II, Chap. IV, Art 4; Rapport de M. Bulmerimicq: Commission des Prises Maritimes, Gand. 1880, 437, 449.

24 See Triquet $\nabla$. Bath, 3 Burrow's Rep. 1480. 
to the statutes of the realm. ${ }^{26}$ Cowell, in his "Interpreter," published a century later, is equally silent, and even treats the law merchant as "a privilege or special law differing from the common law." 26

In $1709^{27}$ it is first referred to 28 in an Act of Parliament, as (on certain points) of force in England. Four years afterwards, however, when Sir Matthew Hale wrote his History of the Common Law, he ignored its existence, and so did Wood in his Institutes, published in 1722 , which repeat the statements made in "Doctor and Student."29 Sir William Blackstone, in his commentaries, which appeared some forty years later, ${ }^{30}$ is the first English text writer to assert that the law of nations is part of the law of the land, and no doubt took this position on account of observations made in a case ${ }^{31}$ in which he was himself of counsel, by Lord Mansfield, a few months before his work appeared from the press. Possibly, also, he was influenced by the assertion of the Roman lawyers that the jus gentium was part of the jus civile, ${ }^{32}$ for it is probable that Blackstone attributed to the jus gentium much that more properly belonged to the jus feciale, and so gave it too wide an international application. ${ }^{83}$

The principle thus declared was received without question in America, and remained unshaken by the Revolution. It was fully applied, from the first, in the courts of the different States, ${ }^{84}$ and in 1789 was put for the United States upon the solid ground of constitutional recognition. It is one of the powers expressly confided to Congress to define and punish offenses against the law of nations. ${ }^{35}$ What these offenses are it is left to that law to decide. The office of Congress is not to declare, but simply to define and prescribe the sanction. ${ }^{36}$

\footnotetext{
25 Dialogue 1, Chapter IV, xi, xxi.

20 Tit. Law Merchant.

27 Holland. Studies in International Law, 193.

287 Anne, Chap. 12.

20 pp. 4, 10 .

$80 \mathrm{IV}, 67.1765$.

$s 2$ Triquet $\mathrm{.} \mathrm{Bath,} 3$ Burrow's Rep., 1480.

s2 Cicero, de officiis, II, Chap. xvii; Dig. I, 1. de Justitia et Jure, 5, 6, 9;

ss See Maine's Ancient Law, Chapter III.

s4 Respublica r. De Longchamps, 1 Dallas' Reports, 111, 114.

35 Art. I. Sec. 8.

36 United States 7. Arjona, 120 United States Reports, 488.
} Gaits, $I$, $i$. 
The courts of the United States and also those of Mexico have a peculiarly wide jurisdiction over questions of international law from the fact that treaties are in those countries made by their Constitution part of the supreme law of the land, and to be enforced as such by the judges of all courts, State and national. ${ }^{37}$ This compels them to deal with many controversies regarded elsewhere as cognizable solely by the executive power. Whoever in these countries may suffer in person or property, by the infraction of a treaty, has precisely the same right to appeal for redress to any proper court, as if his suit rested upon an Act of Congress. It is obrious that this throws the construction of treaties into the hands of the courts. ${ }^{38}$

In a spirit of comity, they always seek to follow that, it any, which may have been already adopted by the executive and legislative departments, ${ }^{39}$ but not if it be manifestly contrary to what seems to them the true intent of the instrument. 40

The meaning of a treaty almost always depends on the sense in which it employs terms of usage in international law. These terms therefore are constantly coming up for definition before American judges, and so far as they do the work intelligently, they add to the future precision of the vocabulary of the science.

The treaty of peace between the United States and Spain, negotiated in 1899,41 opened with the declaration that during the occupation of Cuba by the United States they would "assume and discharge the obligations that may by international law result from the fact of its occupation, for the protection of life and property." What are these obligations? The Court that applies the treaty must determine them; and it must do so as a pure question of legal construction.

Diplomatists, in framing the engagements of nations, often act hastily, at a distance from books of reference, and under an overwhelming pressure of circumstances. It is fortunate that their work is left to be interpreted in the deliberate course of

\footnotetext{
87 Constitution of the United States, Art. VI; Constitution of Mexico, Art. 126.

38 United States v. Rauscher, 119 United States Reports, 407, 4.19.

39 Foster v. Neilson, 2 Peters' Reports, 253, 308.

40 Castro v. DeUriarte, 16 Federal Reporter, 93.

4130 United States Statutes at Large, 1755.
} 
judicial procedure. Nor even if the negotiation of a treaty admits of delay and careful thought, is it often that no occasion of doubt as to its meaning can arise.

Is it not true that rules laid down in the most solemn declarations and conventions are commonly expressed with less precision and certainty than those asserted by courts of justice?

It is, for instance, one of the maxims of the Declaration of Paris, that "Blockades, in order to be binding, must be effective, that is to say, maintained by a force sufficient really to prevent access to the coast of the enemy." But has any power ever seriously contended that these words mean what they literally declare? The question is not whether access is really prevented, but whether it is made really dangerous. Hence it has recently been adjudged that a single cruiser with modern guns of long range may be sufficient to blockade a port, notwithstanding the former practice of stationing a squadron of two or more. 42

Another maxim of this Declaration is that neutral goods with the exception of contraband of war, are not liable to capture under the enemy's flag. But what if they are in fact captured, and in the course of capture injured or destroyed? The failure to provide for this event soon occasioned a suit in the Prize Courts of this country, by the neutral owners of goods seized on a German ship during the Franco-Prussian war, and destroyed with the vessel as an act of war; the decision being that restitution was only demandable as respects the goods existing in specie, or their proceeds, if sold.43

The will of the late Duke of Brunswick called upon the French courts, a few years since, to expound certain clauses in the treaty of 1869 with Switzerland, which were found obscure. It was provided in one article that in "contestations en matiere mobiliêre et personelle" between subjects of the two powers the rule of actor forum rei sequitur should prevail: in another, that "en matiére reelle ou immobilière," suits should be brought where the property lay. Was the term contestation personelle to be understood as meaning those only purely personal, or did it cover suits to determine a succession to immovables, depending upon the validity of a will? Despite the exceptions of the city of Genera, as universal legatee, the jurisdiction of this country, where the duke left large landed possessions, was main-

42 The Olinde Rodrigues, 174. United States Reports, 510.

48 Calvo, Le Droit Int, \$3033. 
tained; as justified both by the true construction of the treaty itself, and by force of the statute law of France (Code of Civil Procedure, Art. 59).44

The latter of these grounds brings into view one general restraint upon the authority of the judge, which is of the first importance, when he is called upon to pass upon treaty obligations.

Wherever a treaty is not a law, it is inferior to the law, that is to the municipal law of the contracting powers.

It has sometimes been asserted that in thosecountries, such for instance as France and Germany, in which treaties or treaties of a certain kind must be ratified by the legislative authority, such a ratification gives them the force of law. This position seems to me hardly tenable. The legislature in such a proceeding acts as a council of State, rather than as a representative of the people or of other constituencies, and really discharges an executive function.

Such I understand to be the view of the courts of this country.45

A treaty, then, if it be no more than a contract, must yield to any municipal law with which it is in conflict. It must be disregarded or set aside by the authority to which it may be confided to determine what the law is and to apply it in controverted cases. Sir Robert Phillimore, as a Judge of an English Admiralty Court, therefore did not hesitate to rule that no British treaty could relieve foreigners from the operation of laws which by the British Constitution were to affect all alike. 46

Even in the United States and Mexico, it may be assumed that a treaty contrary to the Constitution would bedisregarded by the courts, and it is certain that a statute passed after a treaty would be superior to it.47

Nor are courts confined to a comparison of treaties with the municipal law. They must often look, to find their true

4 See the full statement and discussion of this case in the Rerue critique de IEgislation et de Jurisprudence, XXIV, 82.

is See the case of the La Construction, limited, cited and commented upon in Barclay's Companies in France, 20, 85.

16 The Parlement Belge, Law Rep., 4 Probate Division 129, 154 (Reversed, but not on this point. S. C. 5 P. D. 197, 204). Cf. Hall, Treatise on International Law, 199 ; Reg. v. Keyn, Law Reports, 2 Exchequer Division, 160.

4 See Professor Despagnet's paper in the Revue de Droit Int. Public, 1895, II, 184. 
meaning, to the law of the world,-that law which the contracting powers designed to affirm, to extend, or to restrict.

A wide view must be taken upon any question of construction arising upon a treaty between nations. Such papers must be read in the light of the purposes they were designed to promote. They are commonly negotiated to provide for what the general law of nations does notsufficiently secure. This general law must therefore be inspected and ascertained, in order to determine for what, outside of it, the contracting powers have mutually stipulated.

Is it a question of extradition? The court may find it necessary to inquire whether there could be extradition without a treaty. 48

Is it a question of alien ownership in real estate claimed under a treaty which overrides some local statute? The conformity of this statute to the law of nations must be examined. ${ }^{49}$

Is the treaty one of cession? What is ceded may depend on what international law gave power to cede. ${ }^{50}$

Nor does the power of the American court stop here. It considers an award of arbitrators appointed under a treaty as carrying an obligation equal to that imposed by the treaty itself, and equally capable of legal enforcement by judicial process. If the stipulation be that the award is to be accepted as final, then the courts may uphold it as such, even if the executive department should object. 51

It need not be observed what a strength this doctrine has lent, in America, to the proceedings of the tribunal to be organized under the Conventions of The Hague. Should the United States become a party to any controversy before it, its decision will have for them and in their courts the force of an Act of Congress and, so far as it settles private rights, suitors can inroke its aid under every sanction which law can supply.

Hubner, Sainte Croix, Galliani, and Azuni contended for a single prize court for the world, to sit in some free city, with judges drawn from every nation in Europe. Their ideal seems ready to be crowned by even a broader realization, and for one country at least a mode of enforcing judgment seems to exist.

I have thus far spoken more particularly of judicial declar-

48 United States v. Rauscher, 119 United States Reports, 407.

49 Hauenstein v. Lynham, 100 United States Reports 483,484 .

so Mitchel v. United States, 9 Peters' Reports, 711, 733.

51 The La Ninfa, 75 Federal Reporter, 513. 
ation and enforcement of international law as affecting rights of property. It has received hardly less important accessions from the decisions of courts in cases involving questions of personal liberty.

Can one State refuse to permit citizens of another to take up their residence within its limits, or after admitting them, can it expel them against their will?

The extension of commercial intercourse in recent years, between the Eastern and Western nations, and the general acknowledgment of the inherent right of voluntary expatri. ation, have given new point to this inquiry. Publicists have differed in their views as to the controlling principles of law: governments have differed in theirs as to the policy which it might be expedient to pursue. The courts have been appealed to, in actions against executive officers for preventing a landing; or upon writs of habeas corpus in favor of aliens held in legal custody for purposes of deportation; and they have affirmed the right of the legislative or political departments to exclude whom they will, considering such action contrary to no rule of international law, whether it may or may not be regarded as an infringement of international comity. ${ }^{52}$

And here let me say that the comity of nations differs, it seems to me, fundamentally from the law of nations. It has little value for the individual; none as an absolute test of individual right. It is something as to which each nation, speaking through its courts, is a law unto itself.5s

"What is termed the comity of nations," it has been said by one of the American courts of last resort, "is the formal expression and ultimate result of that mutual respect accorded throughout the civilized world by the representatives of each sovereign power to those of every other, in considering the effects of their official acts. Its source is a sentiment of reciprocal regard, founded on identity of position and similarity of institutions." 54

I shall not detain you by remarking on what courts, in all countries alike, have done towards shaping private international law. That lies wholly in their peculiar field, and it is

82 Musgrove v. Chun Teeong Toy, L. R. Appeal Cases, 1891, 272; Fong Yue Ting v. United States, 149 United States Reports, 698.

88 Oakey .. Bennett, 11 Howard's United States Reports, 33, 44; Security Trust Co. $\nabla$. Dodd, Mead \& Co., 173 United States Reports, 624, 629, 635.

- se Fisher, Brown \& Co. $\nabla$. Fielding, 67 Connecticut Reports, 91, 108. 
in their hands that it has gradually gained form and precision.

It is not to be regretted that there is less of unanimity and certainty in judicial decision, in relation to public than in relation to private international law. The scheme of judicial intervention would else be unworkable.

No government can conduct its foreign affairs with confdence and dignity, if any important points are involved as to which the executive and judiciary are not at one. Hence the courts have been careful to keep themselves informed of such transactions at the foreign office as may affect the subjects of pending litigation, and in so doing they have made free use of the doctrine of judicial notice.

The judicial tribunals of every country not only know what all men know, but when the dealings of their government with foreign nations are such as to give or withdraw a private right, may inquire for themselves what those dealings were, and take their information, not in the shape of evidence from the parties, but from public doctuments and even special communications made particularly to them by the proper officer. ${ }^{56}$ Public law may thus be, in a measure, shaped by public policy. But, in the long run, it will be by the public policy of no one nation.

There is a serious objection to Judge-made law in general which has much less of force when that law is of an international description. Statutes are easily and often repealed. The composition of the legislature changes frequently. The best laws, it has been said, are those which abrogate some former law, and remit things to their natural course and level. But the court which makes a precedent is apt to cling to it, and courts have a certain permanence of corporate identity and existence. The precedent was established not as a rule of policy, but of right. To decline to follow it is a confession of error. Such a confession comes more readily when it is called for by the public opinion, not of one country as to a question of domestic concern, but of all countries as to a matter of concern to the world at large. As soon as it is evident that any doctrine which has been judicially asserted as to a point of that nature fails to receive a general consensus of approval, the court which put it forward will seldom decline to qualify or retract the position.

ss Taylor v. Barclay, 2 Simons' Reports, 213, 220; Jones v.-United States, 137, United States Reports, 202, 216. 
An easy way is thus open for retracting any ill-considered step.

The admiralty court in England, in the seventeenth century, issued executions against the body on foreign judgments, at the request of the foreign tribunal, and it was upheld by the courts of common law as warranted by that and by the law of nations. Here not only was the determination of the foreign court held conclusive, but a proper foundation for the immediate issue of domestic process. ${ }^{56}$ Such was not the opinion of the world. The doctrine was weighed by publicists and found wanting. The English courts soon saw that they had gone too far, and in the next century the rule which they had thus sought to import into private international law was quietly dropped, by the same authority by which it had been introduced. ${ }^{57}$

Incidents like these show, no doubt, that judgments of Prize Courts may sometimes come from men not well informed as to the principles with which they have been called on to deal, nor can we forget that judicial tribunals can never be absolutely uninfluenced by the pressure of surrounding public sentiment. It is true also that the judges of no country can be or perhaps should be wholly free from a desire to support the policy of the executive department.

To such causes, an application of the doctrine of "the continuous royage" by the Courts of the United States, during the Civil War, ${ }^{68}$ which has found favor in England, has been attributed by a writer of authority. ${ }^{69}$ Perhaps, however, this particular criticism is sufficiently answered by the similar rulings which have been made by the Prize Courts of France and Italy, ${ }^{60}$ and the declaration put forth by the Institute of International Law in 1896.

But there is a more serious element of weakness in Prize decisions, which has detracted much from their force as compared with those rendered by other tribunals upon subjects less intimately connected with the incidents of war. ${ }^{61}$ It lies in the fact

so Molloy de jure maritino et navali, 476.

57 Sinclair v. Fraser, 20 How. St. Tr., 468.

58 The Bermuda, 3 Wallace's Reports. 514.

59 Hall, International $\mathrm{Law}, 695, \$ 247$, and note.

60 See the cases of the Vrow Houwina, and the Doelwijk, cited in Professor T. S. Woolsey's paper on Neutral Rights and Contraband of War, in the Oatlook, LXIV, 167, and fully reported by Signor Fedozzi in the Revue de Droit Int. XXIX, 65.

62 See the remarks of Lorimer, Institutes of the Law of Nations, II, 297. 
that their work is done mainly flagrante bello, and often in the absence of the party most vitally concerned. This is the owner of the libeled property, who not infrequently is an alien enemy. If such be his national character, it has been the general practice of Prize Courts to refuse him a hearing. ${ }^{62}$

An important step towards a change in this mode of procedure was made by the Supreme Court of the United States in 1870. They held that, under an Act of Congress providing for the confiscation of property of those holding office under the so-called Confederate States, by proceedings in rem conforming as nearly as might be to those in admiralty, the owner, although an enemy in arms, was entitled to appear, by attorney, and make defense. That his title might be assailed in court, it was said, necessarily implied that he might defend it there. ${ }^{63}$

It must be owned that this decision paid no great deference to English precedents in Prize cases, and relied on some in the common law and equity courts which hardly support it. ${ }^{64}$

Is there not, however, much to recommend its general acceptance? Such a step would be one in the same direction with many that have been taken in recent times, in furtherance of the humanities of civilization. The employment of counsel-of those who are themselves officers of the court, charged with the function of defending even the guiltiest offender against the justice and sovereignty of the State-is a kind of intercourse between subjects of belligerent powers which, if it has been technically forbidden by a maxim of international law framed with a different intent, can hardly imperil any true national interest, and is demanded by a rule, not technical but fundamental, Audi alteram partem.

The power of the courts to declare, and so, from time to time, to expand, if not to reduce, the law of nations has rarely been abused. To exercise it wisely and effectually requires a learning, a knowledge of history, a familiarity with current

62 The Falcon, Robinson's Reports, 199 (1805); Halleck, International Law, II, Chap. 32, §27; Wheaton, International Law, Dana's Ed., 480-483, n.

68 ḾcVeigh v. United States, 11 Wallace's Reports, 259, 267 ; Uniteđ States v. 1756 Shares, 5 Blatchford's Reports, 231, 237.

64 Albretcht $\%$. Sussmann, 2 Vesey and Beames' Reports, 326. An opinion of Judge Story has sometimes been cited as deciding that an alien enemy cannot sustain a claim in a prize court. His ruling was simply that as the onus probandi in prize causes rests on the claimant, no title could be set up under a contract of sale made pending the war with an enemy, and therefore void. The Emulous, 1 Gallison's Reports (1813), 563, 571. 
events, a strength of reasoning, a freedom from local prepossessions and partialities, which few attain. Hence, most Judges in international law, have been content to repeat the language of others. They have either followed the greatest of their predecessors on the bench, or relied upon unofficial statements and opinions of jurists of established reputation.

No method could have been better adapted to the orderly and systematic development of this branch of law. It removed any occasion for hasty legislation. It proceeded by analogy to new applications of fundamental principles, but it proceeded with a caution necessarily involved in taking steps in any one country which, unless followed in others, must result in confusion and error. ${ }^{65}$ It elevated the law of nations above the jus civile, the law peculiar to any particular nation. It led English Judges to assert that, at least in Prize cases, it was not to be varied even by the omnipotence of Parliament, to the prejudice of rights gained under it by the humblest subject of a foreign power. ${ }^{66}$ It has frequently led to a construction of Executive orders, affecting the subjects of other goverments, which narrowed their field of operation and practically nullified them, because it was assumed by the court that they could not have been intended to violate what it held to beinternational obligations.

An instructive instance of this judicial enlargement of international law is furnished by a recent decision of the Supreme Court of the United States.

Early in the century, it had been declared from that bench, by Chief Justice Marshall, that the modern usage of nations, as affecting the law of nations, constituted, of itself, no rule for the guidance of courts. It could not act directly upon the thing itself by its own force, but only as it might be adopted by the sovereign power. As regarded the case in hand, the sovereign power of the United States was to be regarded as vested in Congress, and their course would be determined, and properly, by questions of policy. The controversy before the court was over enemy's goods seized and condemned without any legislative authority. It was contended in behalf of the government, that the Executive had had it seized and appropriated rightfully under the laws of war, as established by

65 See The Fladoyen, 1 Rob. Adm. Rep., 135; The Maria, ib., 340.

${ }^{66}$ Holland's Studies in International Law, 194 ; Heathfield $\nabla$. Chilton, 4 Burrow's Rep., 2016. 
modern usage. The court dismissed the libel, because it could "pursue only the law as it is written," and there was no written law to authorize such confiscation.

The Chief Justice treated the ancient and original law of nations as the ultimate source of authority. By that, he declared, the mere existence of war did not authorize the confiscation by judicial proceedings of enemy's goods found on land, and modern usage could not, of itself, give the courts of belligerent powers a wider authority. ${ }^{67}$

It is to be observed in regard to the opinion thus delivered that the course of reasoning was probably influenced by a traditional sense of the power of the American Congress over foreign relations. It had such power under the original organization of the government of the United States, and exercised it in adjudicating prize cases. ${ }^{68}$

During the present year, a somewhat similar question came up in the same court.

In the war between the United States and Spain, a Spanish fishing-smack, taken while making for a blockaded port, was condemned as prize by a court of admiralty in Florida. By the primitive usages of nations, such vessels were as liable to capture and confiscation as any others which might fly an enemy's flag. Sentiments of humanity produced what Merlin described as a sort of tacit convention between all nations of Europe for their exemption. ${ }^{69}$ Lord Stowell, in the English Court of Admiralty, in a case arising in 1798, regarded this as "a rule of comity only, and not of legal decision." The Supreme Court of the United States, on appeal in the case to which I now allude, held that what might have been a matter of comity at the close of the last century, had, by the close of this, ripened into a settled rule of international law; that this was shown by the works of modern publicists, which were to the courts trustworthy evidence of what the law is; and that prize courts were bound to take judicial notice of it, as a part of the law of the United States, and give it full effect, in the absence of any

\footnotetext{
67 Brown v. United States, 8 Cranch's Rep., 110. See the Johanna Emilie, 29 English Law and Equity Rep., 562, in which Dr. Lushington, Judge of the High Court of Admiralty, expressed a different opinion.

68 Journals of Congress, V, 86-90; Penhallow v. Doane, 3 Dallas' Rep., 54, $82,85$.

60 Répertoire de Jurisprudence. Prise Maritime, III, 1, 3.
} 
treaty or other public Act of their own government to the contrary. ${ }^{70}$

If judicial extensions of international law, made in such ways as this, be compared with those which have been attempted from time to time by the political departments of government, I think it will be found that they have proved more durable. They command public confidence more fully. They have less the taint of selfishness; the color of occasion.

Attempts have often been made by neutral powers to formulate and proclaim during a war, as maxims of international law, such rules as would best promote the interests of their own subjects. The Armed Neutrality of 1780 may be taken as an imposing instance of this. The Russian declaration of that year, limiting articles of contraband to munitions of war and sulphur received the adhesion of ten powers within the next two years. ${ }^{71}$ But was it ever seriously taken as anything but a temporary expedient to subserve particular ends under particular circumstances?

Nor can international law be said to have derived any even and acknowledged growth from the awards of special arbitral tribunals. Take that which is perhaps of first importance, made under the Treaty of Washington of 1870 . The principle asserted by the majority of the arbitrators, that it is a violation of international duty for a neutral not to prevent her subjects from fitting out and despatching to a belligerent port, as a matter of mercantile profit, vessels suitable for men of war, has certainly failed to command universal approval. ${ }^{72}$

The growing solidarity of the world, bound together as it is by ocean cables across every sea which outstrip the hours, and now accepting in the main similar principles of social government, demands more certainty in the definitions of international obligations.

The doings of The Hague Conference are a response to this sentiment, the more impressive, because that Conference was called by a power that till in recent times seemed to have little in her institutions that was common to the rest of Europe. The proposition of such a Court as that which is to have its seat at The Hague, would have seemed visionary, had not the 677.

i0 The Paquete Habana, October Term, 1899, 175 United States Reports,

71 Hall, International Law, 673, 8238.

72 Cobbett's Cases on International Law, 268, 288. 
family of nations taken on a new character, as such, during the nineteenth century. It had come to recognize certain standards of international morality. It had come, particularly, to respect the force of judicial decision, pronounced by the tribunals of any one of this great family, but affecting the interests of the subjects of another. It had come even to respect it, although the interests affected might be those of a foreign power itself.

In one conspicuous instance such a determination of sovereign rights had been asked for by one nation at the hands of another-that is of the courts of another.

I refer, of course, to what was done by Great Britain, a few years since, in relation to the controversy between her and the United States as to their territorial jurisdiction over Behring's Sea. She contended that this extended only three miles from the shore of Alaska. The President of the United States maintained that it ran to the middle of Behring's Straits and from the meridian of $172^{\circ}$ to that of $193^{\circ}$ West Longitude. Pending a diplomatic controversy over this question between the two powers, an American revenue cruiser seized a Canadian vessel engaged in seal fishing nearly sixty miles from the Alaskan coast. She was libeled by the United States in the Alaskan court of admiralty, under the statute against fishing for seals in waters subject to their jurisdiction, and a decree of condemnation was passed.

Here was what might have been a casus belli. The. seizure was wrongful, if, as Great Britain asserted, the United States had no jurisdiction beyond the three-mile line. But the spirit of modern civilization makes for peace. It puts right above might. It is more confident that a controversy will be justly settled by a judicial trial, than by a military contest.

The Attorney General of Canada filed a "suggestion" in the Supreme Court of the United States, that a writ of prohibitation should issue against the enforcement of the decree of confiscation, stating that he did so "with the knowledge and approval of the imperial goverment of Great Britain, and that he would be represented by counsel employed by its minister resident at Washington."73 This action was taken in aid of an application couched in similar terms, which was presented by the owner of the vessel. The Attorney-General and SolicitorGeneral of the United States appeared in defence. The Court

78 In re Cooper, 138 United States Reports, 404, 412. 
issued a preliminary rule to show cause; but finally refused the writ on the technical ground that the record did not show that the seizure was made outside of the three-mile line. It was observed in the opinion ${ }^{74}$ that a prohibition could not issue upon the request of the British government, unless the owner of the vessel had made out a case of an infringement of his rights of ownership, as the court had no jurisdiction to pass on abstract political questions. Had, however, the real question of boundary been presented on the record, and made the subject of adjudication, it can not be doubted that both governments would have acquiesced in the result: that of Great Britain because it had invited the judgment, and that of the United States because it had been pronounced by the highest judicial authority in the land, acting under a Constitution which it was its prerogative to interpret and apply.

This case is the more remarkable because no countries have been more sedulous to maintain the immunity of foreign sovereigns from suit than England and the United States. It was early held by the American courts to protect a foreign ship of wat from a libel founded on the jus postliminii, however irregular the proceeding under which it might have been taken from the original owner. ${ }^{75}$ This was also, notwithstanding the opinion of Bynkershoek to the contrary, soon afterwards declared by the French courts to belong equally to anything that might be due from domestic debtors, if attached by proceedings in the nature of a foreign attachment. ${ }^{76}$ Recently it has served to protect the Sultan of Johore from an action in England for a breach of promise of marriage, which the plaintiff asserted that he had made to her while living incognito in that country under the name of Albert Baker. ${ }^{77}$

On one allied point, the law cannot yet be said to be definitely settled. This is the limit of the right of defense when the foreign sovereign is the actor. May not only an answer, but a counter-claim be put in, and thus that same full justice be done

\footnotetext{
74 In re Cooper, 143 United States Rep., 472, 503, 513.

76 The Exchange $\nabla$. McFaddon, 7 Cranch's Reports, 116.

76 Journal du Palais, XIX, 22. S. P. De Haber v. Queen of Portugal. 20 L.J. N. S. Q. B. 488.

77 Mighill $\mathrm{r}$. Sultan of Johore, Law Reports, 1 Q. B. Division, 149. Cf. Calvo, Droit Int. $\$ \$ 1469,1476$; and the paper by Professor Audinet on the case of the Succession to the Duke of Brunswick in the Revue de Droit Int. Public, 1895, II, 385.
} 
to both parties to the controversy to attain which is theobject and rule of the ordinary action? ${ }^{78}$

It was said not many years ago by a distinguished jurist, that "there is no place for the refinement of courts in the rough jurisprudence of nations." 79

For the refinements of form, of technicality, of procedure, No. But for all those higher refinements, which in a large way soften and ennoble the administration of human justice, there is increasing room, and always must be. There can be no substantial difference between the manner in which a court deals with questions of international and of municipal law. International law, in every civilized State, is municipal law. As such, it has in each its sanction. The judgment that may be rendered, would be no judgment, could it not be enforced as. between the parties to the litigation, or as against the res which is the subject of controversy.

Between the executive authorities of treaty powers, their engagements may rest simply on public faith. But so far as their process runs, to the extent that courts administer the law of nations it has its sanction, and every adjudication of this nature tends to confirm a public sentiment by which it is regarded as of binding authority between men and governments alike.

No court indeed can extend its hand to compel a foreign nation to obey its judgments; but its moral force in declaring what is right and just-what is established by common consent of mankind as the true rule of international conduct-this is far weightier than anything attaching to the utterances of kings or parliaments. A court is an arbiter before which contending parties state their claims upon an equal footing,erected for this end, because all men agree that thus can justice be best secured. What speaks for justice, speaks with a voice which no nation, however powerful, can afford to disregard. It is, as one of our associates has finely said, "P'expression souveraine du principe du bien, coordonne arec les exigences de I utilite individuelle ou collective." 80

The power which should go before an international tribunal, and then decline to respect the decree which it had invoked,

78 South African Republic y. La Compagnie Franco-Belge, ete, Law Reports, 1897, 2 Chancery Dirision, 487; 1898, 1 Chancery Division, 190.

79 Hall, Treatise on International Law, 2d Ed. 310, $\mathrm{n}$.

80 Corvi, de I' Existence d' ane Sanction Positive dans le Droit International, 23. Pisa, 1900. 
based upon the jurisprudence of the world, would forfeit the good opinion of mankind. And hardly less endurable is now the state of that nation, which has avowedly violated any rule of international law which is generally held to have been established by judicial decision. It goes against the moral sense of Civilization. Its punishment is none the less serere, because it is simply the natural, unwritten consequences of its acts. Nations live long. They may suffer long. Men may escape remorse for earth, at least, by suicide; after earth it may be by pardon. But no divine mercy awaits the nation that has proved itself unworthy, and its perpetuity of existence keeps it forever at the bar of public opinion. History is the judge; and it is the history of the world of which the greatest power forms so small a part. The record of conviction is not hastily made up; but, once registered, it can never be effaced. 